UDC 547.792"367"722.03/.04

\author{
V. Zazharskyi ${ }^{a}$, M. Parchenko ${ }^{b}$, V. Parchenko ${ }^{b}$, P. Davydenko ${ }^{a}$, O. Kulishenko ${ }^{a}$, \\ N. Zazharska ${ }^{a}$
}

\title{
PHYSICOCHEMICAL PROPERTIES OF NEW S-DERIVATIVES OF 5-(5-BROMOFURAN-2-YL)-4-METHYL-1,2,4-TRIAZOL-3-THIOLS
}

\author{
${ }^{a}$ Dnipro State Agrarian and Economic University, Dnipro, Ukraine \\ b Zaporizhzhia State Medical University, Zaporizhzhia, Ukraine
}

\begin{abstract}
The alkylation of 5-(5-bromofuran-2-yl)-4-methyl-1,2,4-triazole-3-thiol with bromoalkanes was carried out. Synthesis was accomplished by addition of equivalent amounts of bromoalkanes (bromomethane, bromoethane, bromobutane-bromodecane) to 5-(5bromofuran-2-yl)-4-methyl-1,2,4-triazole-3-thiol in a methanol medium in the presence of an equivalent amount of sodium hydroxide. Compounds were obtained with a high yield. The next step was to investigate the reaction of 5-(5-bromofuran-2-yl)-4-methyl1,2,4-triazole-3-thiol with some other halogen-containing compounds, the mechanism of the reaction of which also relates to nucleophilic substitution. As halogen-containing compounds, we used bromoacetone, bromoacetophenone, chloroacetic acid and chloroacetamide. Under these conditions, a series of new compounds were synthesized. Structure of compounds was confirmed by ${ }^{1} \mathrm{H}$ NMR spectroscopy and elemental analysis. The antibacterial activity of the synthesized compounds towards cryogenic strains of Enterobacteriaceae, Pseudomonadaceae, Staphylococcaceae, Bacillaceae, Listeriaceae, Corynebacteriaceae and Saccharomycetaceae families in vitro was also investigated. According to the data obtained, one can conclude that the investigated compounds can compete with kanamycin, a natural broad-spectrum antibiotic from the second generation of aminoglycosides, whose range of action includes gram-positive and gram-negative microorganisms. The compounds involved may be recommended for further investigation of their action against multi-resistant strains of microorganisms.
\end{abstract}

Keywords: S-derivatives of 1,2,4-triazole, 3-alkylthio-4-methyl-5-(5-bromofuran-2-yl)1,2,4-triazoles, synthesis, physicochemical properties, antibacterial activity.

DOI: $10.32434 / 0321-4095-2020-133-6-50-58$

\section{Introduction}

The search for new highly effective and less toxic biologically active compounds is recognized to be the one of the main tasks of pharmaceutical chemistry. The presence of extensive material on the chemistry and biological effects of 1,2,4-triazole derivatives makes it possible to consider them as one of the most promising classes of biologically active compounds with a wide spectrum of action [1]. Unique properties of 1,2,4-triazole make this heterocycle very attractive to investigations [2,3].

Derivatives of sulfur-containing five-membered heterocycles, such as 1,2,4-triazole, have a broad spectrum of biological activity. Numerous drugs contain in their structure 2-amino-thiazole and aminothiazole-2-thione fragments [4]. In recent years, much attention has been paid to the synthesis of condensed systems based on 1,2,4-triazole. Thus, bicyclic thiazolotriazoles were synthesized by the reaction of 5-phenyl-2,4-dihydro-3H-1,2,4-triazole3 -thione with compounds containing cyanomethylene group [5]. A new series of 7-arylazo-5H-3(trifluoromethyl)-6-methyl-1,2,4-triazolo-[3,4-b]1,3,4-thiadiazines was prepared by the reaction of 4-amino-3-trifluoromethyl-5-mercapto-1,2,4triazoles with $\mathrm{N}$-aryl-2-oxo-propane hydrazonoyl chloride in dioxane under reflux in the presence of triethylamine [6]. Synthesis of 6-aryl-thiazolo $[3,2-b][1,2,4]$ triazoles by the reaction of $1 \mathrm{H}-1,2,4-$ triazole-5-thiol with 2-bromo-1-arylethan-1-one was proposed [7]. It was suggested that 6-(4-propoxyphenyl) thiazolo $[3,2-b]-[1,2,4]$ triazole, the one of

(C) V. Zazharskyi, M. Parchenko, V. Parchenko, P. Davydenko, O. Kulishenko, N. Zazharska, 2020

V. Zazharskyi, M. Parchenko, V. Parchenko, P. Davydenko, O. Kulishenko, N. Zazharska 
the compounds obtained, exhibited higher activity than carbamazepine. Polyheterocyclic compounds with anti-inflammatory and antiviral activity were obtained on the basis of thio esters of 1,2,4-triazole [8]. Some derivatives synthesized on the basis of 2-substituted 1-(6-methylthiazolo [3,2-b] [1,2,4] triazol-5-yl) ethane-1-ones exhibited antiviral and antimicrobial activity [9]. An original one-step method for the synthesis of 5,6-disubstituted thiazolo [3,2-b] [1,2,4] triazoles based on the reaction of unsaturated ketones with bis $(1 \mathrm{H}-1,2,4$-triazolyl $)$ sulphoxide was proposed [10]. By the action of 5-aryl-2,4-dihydro-3H-1,2,4-triazole-3-thion on 2-bromo-1-phenylethan-1-one with the subsequent cyclization, 1-phenyl-2- [(3-aryl-1H-1,2,4-triazol5-yl) thio] ethane-1-ones and 2-aryl-6phenylthiazolo $[3,2-b][1,2,4]$ triazoles were prepared [11].

The investigations prove a high reactivity and minor toxicity of derivatives of 1,2,4-triazole [2] and the prospect of their use as potential biologically active compounds $[12,13]$. Also, interesting results were found by concerning the use of certain derivatives of 1,2,4-triazoles as substances of effective growth regulators of plants [14]. It should be noted that derivatives of 1,2,4-triazole can be used as a substance of veterinary drugs [15]. Among the synthesized compounds, substances with antimicrobial [6], antibacterial [14] and anticonvulsant, antiviral and anti-inflammatory activity were detected. The combination of 1,2,4-triazole with different fragments of organic compounds is considered as promising way to obtain some new compounds which would exhibit biological properties [1]. The application of these transformations was disrobed elsewhere [2].

Our attention was drawn to the possibility of combining structural fragments of 1,2,4-triazole-3thiol and halogenated organics in one molecule, since each of these systems individually possesses a wide range of biological properties or is already a structural fragment of molecules of active pharmaceutical ingredients of some drugs $[1,2]$.

Herein, we studied the reactions of 5-(5-bromofuran-2-yl)-4-methyl-1,2,4-triazol-3-thiol with some halogen-containing compounds, confirmed structures of the new compounds using up-to-date instrumental methods of analysis and investigated the antibacterial activity of the compounds involved towards the cryogenic strains of microorganisms of Enterobacteriaceae, Pseudomonadaceae, Staphylococcaceae, Bacillaceae, Listeriaceae, Corynebacteriaceae and Saccharomycetaceae families in vitro.

\section{Material and methods}

All chemicals were reagent grade. The chemical modeling of 5-R-1,2,4-triazole-3-thiols due to the addition of various pharmacophore agents to the sulfur atom, as is known, leads to the appearance of different types of biological activity and changes in toxicity of compounds [14]. We used 5-(5-bromofuran-2-yl)-4-methyl-1,2,4-triazole-3-thiol (1) (Fig. 1) as the initial thiol, which was synthesized according to the scheme given in Fig. 2. The reaction was carried out in accordance with the classical technique [3]. To $0.1 \mathrm{~mol}$ of 5-bromo-furan carboxylic acid, $100 \mathrm{~mL}$ of propane-2-ol and 3 drops of concentrated sulfuric acid were added; the mixture was boiled for 8 hours. The solvent was evaporated, an excess of an aqueous solution of sodium hydrogen carbonate was added to the precipitate to a neutral medium, which further was filtered, and dried. The isopropyl ester of 5-bromo-furan carboxylic acid was obtained, which was converted into the corresponding 5-bromo-furan carboxylic acid hydrazide as follows. To $0.1 \mathrm{~mol}$ of isopropyl ester of 5-bromo-furan carboxylic acid, $0.2 \mathrm{~mL}$ of hydrazine hydrate was added in $100 \mathrm{~mL}$ of methanol, the mixture was boiled for 2 hours, the solvent was evaporated, the precipitate was dried, and the hydrazide of 5-bromofuranecarboxylic acid was obtained. To $0.1 \mathrm{~mol}$ of hydrazide of 5-bromo-furan carboxylic acid in $100 \mathrm{~mL}$ of methanol, $0.1 \mathrm{~mL}$ of methyl isothiocyanate was added dropwise over 30 minutes, the solution was stirred and left for 12 hours. A precipitate was formed, which was filtered off, washed with methanol and dried. The corresponding methylthiosemicarbazide of 5-bromo-furan carboxylic acid was obtained. To $0.1 \mathrm{~mol}$ of methylthiosemicarbazide of 5-bromofuranecarboxylic acid, an excess of $20 \%$ potassium hydroxide solution was added to achieve $\mathrm{pH} 9-10$, the mixture was boiled for 2 hours, cooled, and then acetic acid added to reach $\mathrm{pH} 7-8$. The resulting precipitate was filtered off, washed with water and dried.

At the initial stage, we considered carrying out the alkylation of 5-(5-bromofuran-2-yl)-4-methyl1,2,4-triazole-3-thiol (Fig. 1) with bromoalkanes.

Alkylation was accomplished by the addition of equivalent amounts of bromoalkanes (bromomethane, bromoethane, bromobutanebromodecane) to 5-(5-bromofuran-2-yl)-4-methyl1,2,4-triazole-3-thiol (1) in methanol medium in the presence of an equivalent amount of sodium hydroxide (Fig. 1). The compounds were synthesized with a high yield $(2-10)$ (Fig. 1).

The next step was to investigate the reaction of 5-(5-bromofuran-2-yl)-4-methyl-1,2,4-triazole-3-

Physicochemical properties of new S-derivatives of 5-(5-bromofuran-2-yl)-4-methyl-1,2,4-triazol-3-thiols 


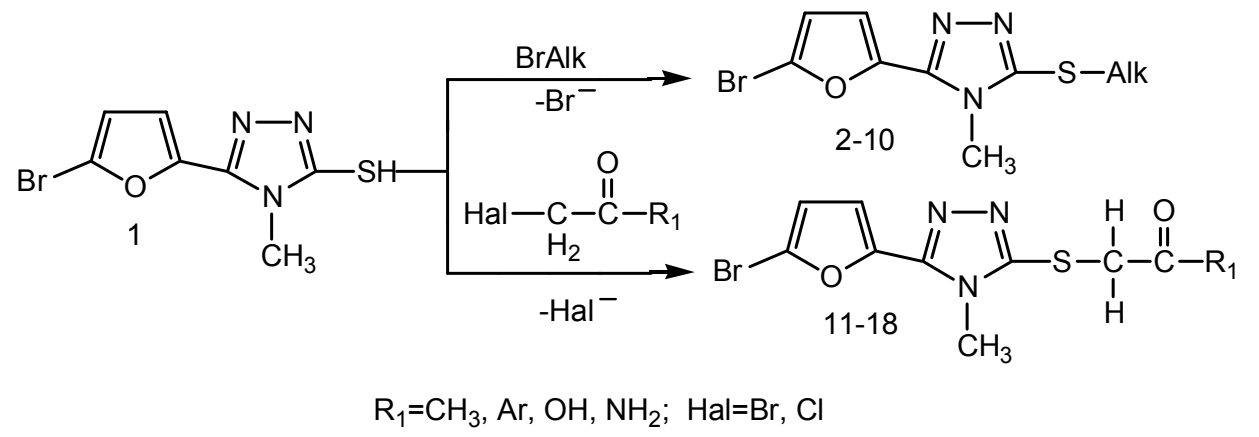

Fig. 1. Scheme of interaction of 5-(5-bromofuran-2-yl)-4-methyl-1,2,4-triazole-3-thiol with some halogen-containing compounds<smiles>CNC(=O)NNC(=O)c1ccc(Br)o1</smiles>

Fig. 2. Scheme of synthesis of 5-(5-bromofuran-2-yl)-4-methyl-1,2,4-triazole-3-thiol

thiol (1) with some other halogen-containing compounds, the mechanism of reaction of which also relates to nucleophilic substitution reactions. As halogen-containing compounds, we used bromoacetone, bromoacetophenone, chloroacetic acid and chloroacetamide. Under these conditions, a series of new compounds were synthesized (1118) (Fig. 1).

The structure of the synthesized compounds was proved by using a complex of physicochemical methods, and their individuality was evidenced by chromatography.

Melting points were determined with a Kofler apparatus. Elemental composition of new compounds was established by means of elemental analyzer ElementarVario L cube (CHNS) (standard sulfanilamide). The ${ }^{1} \mathrm{H}$ NMR spectra were recorded in DMSO-d 6 at $400 \mathrm{MHz}$ by a Varian MR-400 spectrometer and analyzed with ADVASP ${ }^{\mathrm{TM}}$ Analyzer program (Umatek International Inc.); chemical shifts were reported in ppm ( $\delta$ scale) down field with residual protons of the solvent (DMSO-d 6, $\delta=2.49 \mathrm{ppm}$ ) as internal standard.
Antibacterial activity of the investigated compounds was determined by the method of agar disc diffusion. A suspension was prepared from a daily culture of reference cryogenic strains of 17 microorganisms according to the turbidity standard of a bacterial suspension of 0.5 units (Mac Farland 1.5.10 ${ }^{8}$. CFU) using Densimeter II. The resulting suspension was subcultured on Muller-Hinton agar (Himedia), followed by the cultivation in a thermostat for 24 and 48 hours at $37^{\circ} \mathrm{C}$. Discs soaked in appropriate extracts were placed on top of the $\mathrm{g}$ of kanamycin $(0-3-\mu$ subcultures. Discs with 30.0 amino-3-deoxy-alpha-D-glucopyranosyl-(1 "6)-0[6-amino-6-deoxy-alpha-D-glucopyrinazyl-[1" 4)]2-deoxy-D-streptamine) served as a positive control [11]. The chemical formula is $\mathrm{C}_{18} \mathrm{H}_{36} \mathrm{~N}_{4} \mathrm{O}_{11}$ (Fig. 3). Discs with $15.0 \mathrm{mg}$ of amphotericinin (1R, 3S, 5R, 6R, 9R, 11R, 15S, 16R, 17R, 18S, 19E, 21E, 23E, 25E, 27E, 29E, 31E, 33R, 35S, 36R, 37S)-33-Dmannopyranosyl)oxy]- $\beta$ [(3-amino-3,6-dideoxy- 1,3 , $5,6,9,11,17,37$-octahydroxy-15, 16, 18- trimethyl13-oxo-14, 39-dioxabicyclo [33.3.1] nonatriaconta19, 21, 23, 25, 27, 29, 31-heptaene36-carboxylic acid) 
were also used as a second control towards Candida albicans. After 24 hours of incubation, the diameter of the culture growth inhibition zone was measured using a template for measuring the size of microorganism growth inhibition zones (Antibiotic Zone ScaleC, model DW297, India) and TpsDig2 software.

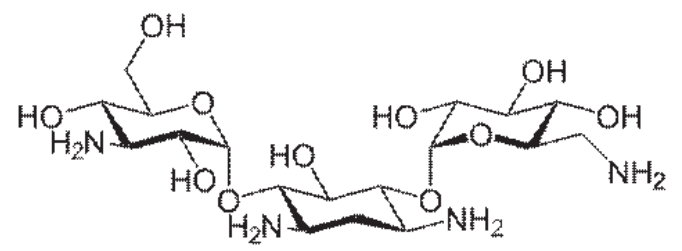

Fig. 3. Spatial structure of kanamycin

The compounds were used with two concentrations: $0.1 \%$ and $1.0 \%$. These two concentrations are indicated by the test group with the corresponding compound number.

\section{Results and discussion}

3-Alkylthio derivatives of 1,2,4-triazoles are usually characterized by antimicrobial and antifungal activities [3,14]. The presence of a keto-group, a carboxyl group or an amide in the molecules of derivatives of 1,2,4-triazole causes the appearance of anticonvulsant [3], immunomodulating [14] or diuretic [13] actions, respectively.

According to the results of the experiment, a number of new compounds not described in the literature $(2-10)$ (Table 1) were prepared, the physicochemical properties of which are given in Tables 1-3.

3-Alkylthio-4-methyl-5-(5-bromofuran-2-yl)1,2,4-triazoles $(2-10)$ are white crystalline compounds, they are practically insoluble in water and soluble in dimethylformamide. For analysis, 3-alkylthio-4-methyl-5-(5-bromofuran-2-yl)-1,2,4triazoles was recrystallized from a 1:1 mixture of methanol and water.
Table 1

Some properties of 3-alkylthio-4-methyl-5-(5bromofuran-2-yl)-1,2,4-triazoles<smiles>Cn1c(S[AlH2])nnc1-c1ccc(Br)o1</smiles>

\begin{tabular}{c|c|c|c|c}
\hline Compound & Alk & $\begin{array}{c}\text { Melting } \\
\text { point, }{ }^{0} \mathrm{C}\end{array}$ & Formula & $\begin{array}{c}\text { Yield, } \\
\%\end{array}$ \\
\hline 2 & $\mathrm{CH}_{3}$ & $100-102$ & $\mathrm{C}_{8} \mathrm{H}_{8} \mathrm{BrN}_{3} \mathrm{OS}$ & 75 \\
\hline 3 & $\mathrm{C}_{2} \mathrm{H}_{5}$ & $155-157$ & $\mathrm{C}_{9} \mathrm{H}_{10} \mathrm{BrN}_{3} \mathrm{OS}$ & 74 \\
\hline 4 & $\mathrm{C}_{4} \mathrm{H}_{9}$ & $86-88$ & $\mathrm{C}_{11} \mathrm{H}_{14} \mathrm{BrN}_{3} \mathrm{OS}$ & 80 \\
\hline 5 & $\mathrm{C}_{5} \mathrm{H}_{11}$ & $115-117$ & $\mathrm{C}_{12} \mathrm{H}_{16} \mathrm{BrN}_{3} \mathrm{OS}$ & 78 \\
\hline 6 & $\mathrm{C}_{6} \mathrm{H}_{13}$ & $95-97$ & $\mathrm{C}_{13} \mathrm{H}_{18} \mathrm{BrN}_{3} \mathrm{OS}$ & 84 \\
\hline 7 & $\mathrm{C}_{7} \mathrm{H}_{15}$ & $100-102$ & $\mathrm{C}_{14} \mathrm{H}_{20} \mathrm{BrN}_{3} \mathrm{OS}$ & 81 \\
\hline 8 & $\mathrm{C}_{8} \mathrm{H}_{17}$ & $99-101$ & $\mathrm{C}_{15} \mathrm{H}_{22} \mathrm{BrN}_{3} \mathrm{OS}$ & 78 \\
\hline 9 & $\mathrm{C}_{9} \mathrm{H}_{19}$ & $96-98$ & $\mathrm{C}_{16} \mathrm{H}_{24} \mathrm{BrN}_{3} \mathrm{OS}$ & 74 \\
\hline 10 & $\mathrm{C}_{10} \mathrm{H}_{21}$ & $98-100$ & $\mathrm{C}_{17} \mathrm{H}_{26} \mathrm{BrN}_{3} \mathrm{OS}$ & 79 \\
\hline
\end{tabular}

Analyzing the ${ }^{1} \mathrm{H}$ NMR spectra of the synthesized compounds (Table 3 ), we can draw some conclusions. There are characteristic signals of the furan cycle that are observed in the region typical of aromatic compounds in the form of doublets and multiplets at $6.66-6.85$ and $7.08-7.23 \mathrm{ppm}$ with a small spin-spin interaction. The residues of the alkyl substituents of the compounds are characterized by splitting: for the methyl-extended singlet, ethyl-triplet and quartet, isopropyl-duplex and singlet, and for butyl-complex triplets and quartiles in the variation of millions of particles. With a further increase of the alkyl radical, the number of quartets and multiplets increases. The methyl group in the 4 position of 1,2,4-triazole is recorded as a singlet in the region of $3.36-3.84 \mathrm{ppm}$.

S-derivatives of 5-(5-bromofuran-2-yl)-4methyl-1,2,4-triazole-3-thiols (11-18) (Tables 4 and 5) are crystalline compounds of light yellow $(11,17)$ or

Table 2

Elemental composition of 3-alkylthio-4-methyl-5-(5-bromofuran-2-yl)-1,2,4-triazoles

\begin{tabular}{c|c|c|c|c|c|c|c|c}
\hline \multirow{2}{*}{ No. } & \multicolumn{4}{|c|}{ Found, $\%$} & \multicolumn{4}{c}{ Calculated, \% } \\
\cline { 2 - 8 } & $\mathrm{C}$ & $\mathrm{H}$ & $\mathrm{N}$ & $\mathrm{S}$ & $\mathrm{C}$ & $\mathrm{H}$ & $\mathrm{N}$ & $\mathrm{S}$ \\
\hline 2 & 35.00 & 2.97 & 15.27 & 11.64 & 35.05 & 2.94 & 15.33 & 11.70 \\
\hline 3 & 37.44 & 3.47 & 14.64 & 11.15 & 37.51 & 3.50 & 14.58 & 11.13 \\
\hline 4 & 41.57 & 4.43 & 13.24 & 10.10 & 41.78 & 4.46 & 13.29 & 10.14 \\
\hline 5 & 43.59 & 4.85 & 12.76 & 9.67 & 43.64 & 4.88 & 12.72 & 9.71 \\
\hline 6 & 45.33 & 5.25 & 12.19 & 9.29 & 45.35 & 5.27 & 12.21 & 9.31 \\
\hline 7 & 46.87 & 5.57 & 11.69 & 8.94 & 46.93 & 5.63 & 11.73 & 8.95 \\
\hline 8 & 48.29 & 5.97 & 11.33 & 8.58 & 48.39 & 5.96 & 11.29 & 8.61 \\
\hline 9 & 49.57 & 6.13 & 10.79 & 8.28 & 49.74 & 6.26 & 10.88 & 8.30 \\
\hline 10 & 50.46 & 6.47 & 10.43 & 7.97 & 51.00 & 6.55 & 10.55 & 8.01 \\
\hline
\end{tabular}


Table 3

Data of ${ }^{1} \mathrm{H}$ NMR spectra of 3-alkylthio-4-methyl-5-(5-bromofuran-2-yl)-1,2,4-triazoles

\begin{tabular}{|c|c|c|c|c|c|}
\hline \multirow{3}{*}{ No. } & \multirow{3}{*}{ Alk } & \multirow{3}{*}{$\mathrm{CH}_{3}, 3 \mathrm{H}$} & \multicolumn{3}{|c|}{$\delta_{\mathrm{H}}, \mathrm{ppm} ; \mathrm{J}, \mathrm{Hz} ; \mathrm{DMSO}-\mathrm{d}_{6}$} \\
\hline & & & \multirow{2}{*}{ Alk } & \multicolumn{2}{|c|}{ Furan cycle } \\
\hline & & & & $1 \mathrm{H}, \beta$-position (13) & $1 \mathrm{H}, \beta^{\prime}$-position (12) \\
\hline 2 & $\mathrm{CH}_{3}$ & $3.61-3.63 \mathrm{~m}$ & $2.59-2.61 \mathrm{~m} \mathrm{(3H)}$ & $7.08-7.11 \mathrm{~m}$ & $6.81-6.83 \mathrm{~m}$ \\
\hline 3 & $\mathrm{C}_{2} \mathrm{H}_{5}$ & $3.36 \mathrm{~s}$ & $\begin{array}{l}1.29 \text { t }(J=7.32,3 \mathrm{H}) \\
3.13 \mathrm{q}(J=7.12,2 \mathrm{H})\end{array}$ & $7.14 \mathrm{~d}(J=3.66)$ & $6.85 \mathrm{~d}(J=3.66)$ \\
\hline 4 & $\mathrm{C}_{4} \mathrm{H}_{9}$ & $3.83 \mathrm{~s}$ & $\begin{array}{l}3.12 \mathrm{t}(J=7.1,2 \mathrm{H}) \\
1.70 \mathrm{q}(J=7.1,2 \mathrm{H}) \\
1.49-1.38 \mathrm{~m}(2 \mathrm{H}) \\
0.95 \mathrm{t}(J=8.0,3 \mathrm{H})\end{array}$ & $7.23 \mathrm{~d}(J=3.36)$ & $6.66 \mathrm{~d}(J=3.36)$ \\
\hline 5 & $\mathrm{C}_{5} \mathrm{H}_{11}$ & $3.84 \mathrm{~s}$ & $\begin{array}{c}3.17 \mathrm{t}(J=7.1,2 \mathrm{H}), \\
1.70 \mathrm{q}(J=7.0,2 \mathrm{H}), \\
1.40 \mathrm{dq}(J=8.2,6.6,2 \mathrm{H}), \\
1.36-1.25 \mathrm{~m}(4 \mathrm{H}), \\
0.93-0.84 \mathrm{~m}(3 \mathrm{H})\end{array}$ & $7.23 \mathrm{~d}(J=3.36)$ & $6.66 \mathrm{~d}(J=3.05)$ \\
\hline 6 & $\mathrm{C}_{6} \mathrm{H}_{13}$ & $3.34 \mathrm{~s}$ & $\begin{array}{l}0.85 \mathrm{t}(\mathrm{J}=6.56,3 \mathrm{H}) ; 1.21-1.28 \mathrm{~m}(2 \mathrm{H}) ; \\
1.34-1.40 \mathrm{~m}(2 \mathrm{H}) ; 1.60-1.68 \mathrm{~m}(2 \mathrm{H}) ; \\
3.13 \mathrm{t}(\mathrm{J}=7.02,2 \mathrm{H}) ; 3.63-3.68 \mathrm{~m}(2 \mathrm{H})\end{array}$ & $7.12-7.14 \mathrm{~m}$ & $6.85-6.87 \mathrm{~m}$ \\
\hline 7 & $\mathrm{C}_{7} \mathrm{H}_{15}$ & $3.67 \mathrm{~s}$ & $\begin{array}{c}0.84 \mathrm{~d}(\mathrm{~J}=6.71,3 \mathrm{H}) ; 1.18-1.37 \mathrm{~m}(6 \mathrm{H}) ; \\
1.62-1.66 \mathrm{~m}(2 \mathrm{H}) ; \\
3.10-3.15 \mathrm{~m}(2 \mathrm{H}) ; 3.34 \mathrm{~s}(2 \mathrm{H})\end{array}$ & $7.14 \mathrm{~d}(J=3.66)$ & $6.86 \mathrm{~d}(J=3.66)$ \\
\hline 8 & $\mathrm{C}_{8} \mathrm{H}_{17}$ & $3.67 \mathrm{~s}$ & $\begin{array}{c}0.81-0.86 \mathrm{~m}(3 \mathrm{H}) ; 1.23 \text { br. } \mathrm{s}(6 \mathrm{H}) \\
1.35 \mathrm{~d}(J=7.02,2 \mathrm{H}) ; 1.64 \mathrm{q}(J=7.32,2 \mathrm{H}) \\
3.12 \mathrm{t}(J=7.32,2 \mathrm{H}) ; 3.64 \mathrm{~s}(2 \mathrm{H})\end{array}$ & $7.13 \mathrm{~d}(J=3.36)$ & $6.86 \mathrm{~d}(J=3.66)$ \\
\hline 9 & $\mathrm{C}_{9} \mathrm{H}_{19}$ & $3.67 \mathrm{~s}$ & $\begin{array}{c}0.81-0.86 \mathrm{~m}(3 \mathrm{H}) 1.23 \text { br. } \mathrm{s}(6 \mathrm{H}) ; \\
1.35 \mathrm{~d}(J=7.02 \mathrm{~Hz}, 2 \mathrm{H}) ; 1.64 \mathrm{q}(J=7.32,2 \mathrm{H}) \\
3.12 \mathrm{t}(J=7.32,2 \mathrm{H}) ; 3.64 \mathrm{~s}(\mathrm{~s}, 2 \mathrm{H}) \\
\end{array}$ & $7.13 \mathrm{dd}(J=3.66,1.53)$ & $6.86 \mathrm{~d}(J=3.66)$ \\
\hline 10 & $\mathrm{C}_{10} \mathrm{H}_{21}$ & $3.67 \mathrm{~s}$ & $\begin{array}{c}0.81-0.86 \mathrm{~m}(3 \mathrm{H}) ; 1.23 \text { br. } \mathrm{s}(6 \mathrm{H}) \\
1.35 \mathrm{~d}(J=7.02,2 \mathrm{H}) ; 1.64 \mathrm{q}(J=7.32,2 \mathrm{H}) \\
3.12 \mathrm{t}(J=7.32,2 \mathrm{H}) ; 3.64 \mathrm{~s}(2 \mathrm{H})\end{array}$ & $7.13 \mathrm{dd}(J=3.66)$ & $6.86 \mathrm{~d}(J=3.66)$ \\
\hline
\end{tabular}

white $(12-16,18)$ colors; they are practically insoluble in water and soluble in dimethylformamide. For analysis, all synthesized compounds were recrystallized from methanol. ${ }^{1} \mathrm{H}$ NMR spectra of compounds showed a singlet signal of a methylene linker in a weak field in the region of 3.66-4.91 ppm (Table 6). It is noteworthy that the aromatic system of phenyl and its substituted analogs actually resonates in the form of duplets and triplets. Particular attention should be drawn to the constant of spin-spin interaction for fluorine substituents in the phenyl ring, which drops when the fluorine atom is removed from the $\mathrm{H}^{2}$ atoms. Having in mind this phenomenon, one can suggest that compound 15 exhibits a less stable aromatic system and it is the most stable for compound 16. Characteristic signals of the furan cycle were observed in the region typical of aromatic compounds in the form of multiplets or doublets at $6.82-6.85$ and $7.11-7.20 \mathrm{ppm}$.

The moderate sensitivity of microorganisms of
Escherichia coli strain 055 K 59 No. 3912/41 to 1.0\% solution of the compound 12 of the experimental group, which is $13.3 \%(1.7 \mathrm{~mm})$ above control was determined. Other experimental groups appeared to be resistant to this strain. The growth retardation zone varied in the range from 0 (group 14) to $11.0 \mathrm{~mm}$ (group 11) when the concentration of the compound was $0.1 \%$; and it was in range from 10.2 (groups 15 and 18) to $11.3 \mathrm{~mm}$ (group 11) when the concentration of the compound was $1 \%$.

Analyzing the effectiveness on Enterococus faecalis ATCC No. 19433, we found fluctuations in the growth retardation zone of more than $10 \mathrm{~mm}$ in all groups, and this indicator is slightly below control by $5.4-6.9 \%$ in 11 and $15-18$ groups. A similar phenomenon was observed with respect to the action of Klebciella pneumoniae K-56 No. 3534/51, Salmonella typhimurium 144 and Salmonella adobraco: a moderately sensitive growth inhibition of Klebciella pneumoniae was detected under the influence of $1 \%$ 
Some properties of S-derivatives of 3-alkylthio-4-methyl-5-(5-bromofuran-2-yl)-1,2,4-triazoles<smiles>[R]C(=O)CSc1nnc(-c2ccc(Br)o2)n1C</smiles>

\begin{tabular}{c|c|c|c|c}
\hline Compound & $\mathrm{R}_{1}$ & Melting point, ${ }^{0} \mathrm{C}$ & Formula & Yield, \% \\
\hline 11 & $\mathrm{CH}_{3}$ & $192-194$ & $\mathrm{C}_{10} \mathrm{H}_{10} \mathrm{BrN}_{3} \mathrm{O}_{2} \mathrm{~S}$ & 68 \\
\hline 12 & $\mathrm{OH}$ & $196-198$ & $\mathrm{C}_{9} \mathrm{H}_{8} \mathrm{BrN}_{3} \mathrm{O}_{3} \mathrm{~S}$ & 88 \\
\hline 13 & $\mathrm{NH}_{2}$ & $177-179$ & $\mathrm{C}_{9} \mathrm{H}_{9} \mathrm{BrN}_{4} \mathrm{O}_{2} \mathrm{~S}$ & 87 \\
\hline 14 & $\mathrm{C}_{6} \mathrm{H}_{5}$ & $151-153$ & $\mathrm{C}_{15} \mathrm{H}_{12} \mathrm{BrN}_{3} \mathrm{O}_{2} \mathrm{~S}$ & 59 \\
\hline 15 & $\mathrm{C}_{6} \mathrm{H}_{4}-2-\mathrm{F}$ & $156-158$ & $\mathrm{C}_{15} \mathrm{H}_{11} \mathrm{BrFN}_{3} \mathrm{O}_{2} \mathrm{~S}$ & 72 \\
\hline 16 & $\mathrm{C}_{6} \mathrm{H}_{4}-3-\mathrm{F}$ & $159-161$ & $\mathrm{C}_{15} \mathrm{H}_{11} \mathrm{BrFN}_{3} \mathrm{O}_{2} \mathrm{~S}$ & 76 \\
\hline 17 & $\mathrm{C}_{6} \mathrm{H}_{4}-4-\mathrm{F}$ & $169-171$ & $\mathrm{C}_{15} \mathrm{H}_{11} \mathrm{BrFN}_{3} \mathrm{O}_{2} \mathrm{~S}$ & 69 \\
\hline 18 & $\mathrm{C}_{6} \mathrm{H}_{4}-4-\mathrm{OCH}_{3}$ & $144-146$ & $\mathrm{C}_{16} \mathrm{H}_{14} \mathrm{BrN}_{3} \mathrm{O}_{3} \mathrm{~S}$ & 67 \\
\hline
\end{tabular}

Table 5

Elemental composition of S-derivatives of 3-alkylthio-4-methyl-5-(5-bromofuran-2-yl)-1,2,4-triazoles

\begin{tabular}{c|c|c|c|c|c|c|c|c}
\hline \multirow{2}{*}{ No. } & \multicolumn{5}{|c|}{ Found, \% } & \multicolumn{4}{c}{ Calculated, \% } \\
\cline { 2 - 9 } & $\mathrm{C}$ & $\mathrm{H}$ & $\mathrm{N}$ & $\mathrm{S}$ & $\mathrm{C}$ & $\mathrm{H}$ & $\mathrm{N}$ & $\mathrm{S}$ \\
\hline 11 & 37.78 & 3.17 & 13.33 & 10.15 & 37.99 & 3.19 & 13.29 & 10.14 \\
\hline 12 & 33.88 & 2.55 & 13.19 & 10.10 & 33.98 & 2.53 & 13.21 & 10.08 \\
\hline 13 & 33.97 & 2.86 & 17.65 & 10.12 & 34.08 & 2.86 & 17.67 & 10.11 \\
\hline 14 & 47.57 & 3.22 & 11.13 & 8.48 & 47.63 & 3.20 & 11.11 & 8.48 \\
\hline 15 & 45.43 & 2.77 & 10.57 & 8.03 & 45.47 & 2.80 & 10.60 & 8.09 \\
\hline 16 & 45.54 & 2.71 & 10.51 & 8.07 & 45.47 & 2.80 & 10.60 & 8.09 \\
\hline 17 & 45.37 & 2.71 & 10.65 & 8.13 & 45.47 & 2.80 & 10.60 & 8.09 \\
\hline 18 & 46.88 & 3.44 & 10.17 & 7.77 & 47.07 & 3.46 & 10.29 & 7.85 \\
\hline
\end{tabular}

concentration in the $11,12,17$ and 18 groups (growth retardation range being $12.1-13.3 \mathrm{~mm})$. For Salmonella typhimurium, such effect was observed only in group 18 when the concentration of the compound was $1.0 \%$ (the growth retardation zone being $14.1 \mathrm{~mm})$. We have found a moderately sensitive antibacterial effect on the strain Pseudomonas aeruginosa ATCC No. 2853 (F) under the action of $1.0 \%$ concentration of 13,17 and 18 groups (the growth inhibition zone was 11.4, 10.1 and $10.3 \mathrm{~mm}$, respectively).

At the same time, inhibition of the growth of microorganisms of Staphylococcus aureus ATCC No. 25923 was detected. A moderate sensitivity of microorganisms was detected in 15,16 and 18 groups (11.1; 13.3 and $10.2 \mathrm{~mm}$, respectively) under the influence of $0.1 \%$ solution of the substances, whereas it was within $10.2-14.8 \mathrm{~mm}$ for $13-18$ samples at $1.0 \%$. A moderate sensitivity of Staphylococcus epidermidis ATCC No. 14990 was also detected: the growth retardation zone at $1.0 \%$ was $10.7,10.4$ and
$13.5 \mathrm{~mm}$ for 12,15 and 17 groups, respectively.

We found a moderate antibacterial activity on Bacillus subtiliss ATSC No. 6633. For $0.1 \%$ concentration, the microbial growth inhibition was stated only in the 17 and 18 groups. For $1.0 \%$ concentration, $12,13,14,16$ and 18 groups showed the growth retardation zone of 10.4, 12.6, 10.9, 11.3 and $10.5 \mathrm{~mm}$, respectively.

Antibacterial effect was also found on the microorganisms from the family Listeriaceae. Listeria monocytogenes ATCC No. 19112 demonstrated a moderate inhibition zone of 10.4 and $10.7 \mathrm{~mm}$ for the 13 and 14 groups, respectively (1.0\%). Listeria ivanovi revealed the inhibition zone within 10.3$14.3 \mathrm{~mm}$ for the $11-14$ and 19 groups. Listeria innocua ATCC No. 33090 exhibited the inhibition zone from 10.2 to $14.7 \mathrm{~mm}$ for the $11-14$ and $17-$ 18 groups.

Thus, there is a positive tendency to inhibit the growth of microorganisms of the family Nocardiaceae and Saccharomycetaceae. 
Table 6

Data of ${ }^{1} \mathrm{H}$ NMR-spectra of S-derivatives of 3-alkylthio-4-methyl-5-(5-bromofuran-2-yl)-1,2,4-triazoles

\begin{tabular}{|c|c|c|c|c|c|c|}
\hline \multirow{3}{*}{ No. } & \multirow{3}{*}{$\mathrm{R}_{1}$} & \multirow{3}{*}{$\mathrm{C}_{3}, 3 \mathrm{H}$} & \multicolumn{4}{|c|}{$\delta_{\mathrm{H}}, \mathrm{ppm} ; \mathrm{J}, \mathrm{Hz} ; \mathrm{DMSO}-\mathrm{d}_{6}$} \\
\hline & & & \multirow{2}{*}{$\begin{array}{r}\text { Methylene linker } \\
2 \mathrm{H},-\mathrm{S}-\mathrm{CH}_{2}-\mathrm{C}(\mathrm{O})-\end{array}$} & \multirow{2}{*}{$\mathrm{R}_{1}$} & \multicolumn{2}{|c|}{ Furan cycle } \\
\hline & & & & & $1 \mathrm{H}, \beta$-position (13) & $1 \mathrm{H}, \beta^{\prime}$-position $(12$ \\
\hline 11 & $\mathrm{CH}_{3}$ & 3.32 br.s. & $4.22 \mathrm{~s}, 4.39 \mathrm{~s}$ & $2.21 \mathrm{~s}(3 \mathrm{H})$ & $7.20 \mathrm{~d}(J=3.66)$ & $6.85 \mathrm{~d}(J=3.66)$ \\
\hline 12 & $\mathrm{OH}$ & $2.47 \mathrm{~s}$ & $3.66 \mathrm{~s}$ & $\begin{array}{c}- \\
-\end{array}$ & $7.20 \mathrm{~d}(J=3.66)$ & $6.85 \mathrm{~d}(J=3.66)$ \\
\hline 13 & $\mathrm{NH}_{2}$ & $3.67 \mathrm{~s}$ & $3.83 \mathrm{~s}$ & 7.63 br.s & $7.11 \mathrm{~d}(J=3.36)$ & $6.83 \mathrm{~d}(J=3.36)$ \\
\hline 14 & $\mathrm{C}_{6} \mathrm{H}_{5}$ & $3.72 \mathrm{~s}$ & $4.92 \mathrm{~s}$ & $\begin{array}{l}7.55 \mathrm{t}(J=7.48,2 \mathrm{H}) \\
7.68 \mathrm{t}(J=7.02,1 \mathrm{H}) \\
8.02 \mathrm{~d}(J=7.93,2 \mathrm{H})\end{array}$ & $7.14 \mathrm{~d}(J=2.75)$ & $6.86 \mathrm{~d}(J=3.05)$ \\
\hline 15 & $\mathrm{C}_{6} \mathrm{H}_{4}-2-\mathrm{F}$ & $3.67 \mathrm{~s}$ & $4.78 \mathrm{~d}(J=2.44)$ & $\begin{array}{c}7.31-7.41 \mathrm{~m}(2 \mathrm{H}) \\
7.68 \mathrm{~d}(J=6.71,1 \mathrm{H}) \\
7.86 \mathrm{~d}(\mathrm{t}, J=7.63,1 \mathrm{H})\end{array}$ & $7.09-7.12 \mathrm{~m}$ & $6.83 \mathrm{~d}(J=3.36)$ \\
\hline 16 & $\mathrm{C}_{6} \mathrm{H}_{4}-3-\mathrm{F}$ & $3.69 \mathrm{~s}$ & $4.87 \mathrm{~s}$ & $\begin{array}{c}7.51 \mathrm{td}(J=8.16,1.98,1 \mathrm{H}) \\
7.58 \mathrm{td}(J=7.93,5.80,1 \mathrm{H}) \\
7.78 \mathrm{dd}(J=9.92,2.59,1 \mathrm{H}) \\
7.84 \mathrm{~d}(J=7.93,1 \mathrm{H})\end{array}$ & $7.11 \mathrm{~d}(J=3.36)$ & $6.83 \mathrm{~d}(J=3.66)$ \\
\hline 17 & $\mathrm{C}_{6} \mathrm{H}_{4}-4-\mathrm{F}$ & $3.72 \mathrm{~s}$ & $4.91 \mathrm{~s}$ & $\begin{array}{c}7.38 \mathrm{t}(J=8.85,2 \mathrm{H}) 8.11 \\
\mathrm{dd}(J=8.70,5.65,2 \mathrm{H})\end{array}$ & $7.14 \mathrm{~d}(J=3.36)$ & $6.85 \mathrm{~d}(J=3.36)$ \\
\hline 18 & $\mathrm{C}_{6} \mathrm{H}_{4}-4-\mathrm{OCH}_{3}$ & $3.68 \mathrm{~d}$ & $4.82 \mathrm{~d}(J=2.7,2 \mathrm{H})$ & $\begin{array}{c}3.68 \mathrm{~d}(J=2.75,6 \mathrm{H}) \\
7.01-7.05 \mathrm{~m}(1 \mathrm{H}) \\
7.22 \mathrm{~d}(J=8.85,1 \mathrm{H}) \\
7.93-8.03 \mathrm{~m}(2 \mathrm{H})\end{array}$ & $\begin{array}{c}7.11 \mathrm{dd}(J=3.66 \\
1.53)\end{array}$ & $6.82-6.85 \mathrm{~m}(1 \mathrm{H})$ \\
\hline
\end{tabular}

\section{Conclusions}

The reaction of 5-(5-bromofuran-2-yl)-4methyl-1,2,4-triasole-3-thiol with some halogencontaining compounds was investigated for the first time. A series of new 3-alkylthio-4-methyl-5-(5bromofuran-2-yl)-1,2,4-triazoles and some S-substituted 5-(5-bromofuran-2-yl)-4-methyl-1,2,4triazole-3-thiols were synthesized. The structure of the synthesized compounds was confirmed by elemental analysis and ${ }^{1} \mathrm{H}$ NMR spectroscopy. The antibacterial activity of the synthesized compounds (11-18) towards the cryogenic strains of Enterococus faecalis, Proteus mirabilis, Proteus vulgaris, Serratia marcense, Salmonella adobraco, Salmonella typhimurium, Staphylococcus epidermidis, Bacillus subtilis, Listeria ivanovi, Listeria innocua, Listeria monocytogenes, Campylobacter jejuni, Rhodococcus equi and Candida albicans was also investigated. According to the data obtained, one can conclude that the investigated compounds can compete with kanamycin, a natural broad-spectrum antibiotic from the second generation of aminoglycosides, whose range of action includes gram-positive and gramnegative microorganisms. Thus, the compounds involved may be recommended for further investigations of their action against multi-resistant strains of microorganisms.

\section{REFERENCES}

1. Design, synthesis and biological evaluation of Schiff bases of 4-amino-1,2,4-triazole derivatives as potent angiotensin converting enzyme inhibitors and antioxidant activities / Saadaoui I., Krichen F., Ben Salah B., Ben Mansour R., Miled N., Bougatef A., Kossentini M. // J. Mol. Struct. - 2019. - Vol.1180. - P.344354.

2. Bihdan O.A., Parchenko V.V. Some aspects of synthesis 3-(2-florphenyl)-6-R1-[1,2,4]triazol[3,4-b][1,3,4]thiadiazole and 3-(2-, 3-ftorphenyl)-6-R2-7H[1,2,4]triazolo[1,3,4]tiadiazines // Res. J. Pharm. Biol. Chem. Sci. - 2018. - Vol.9. - No. 3. P.463-470.

3. Studying of physico-chemical properties of 5-(2-,3fluorophenyl)-4-((aryl-, geteryl) yliden) amino-1,2,4-triazole-3thiols and any of their retrievalproducts / Bihdan O., Parchenko V., Zazharskyi V., Fotina T., Davydenko P. // Res. J. Pharm. Biol. Chem. Sci. - 2019. - Vol.10. - No. 1. - P.464-474.

4. Oxford handbook of practical drug therapy / Richards D., Coleman J., Reynolds J., Aronson J. - Oxford, New York: Oxford University Press, 2011.

5. One pot synthesis and reactions of novel 5-amino[1,3]thiazolo[3,2-b][1,2,4]triazoles / El-Sherief H.A.H., Hozien Z.A., El-Mahdy A.F.M., Sarhan A.A.O. // Arkivoc. - 2011. - Vol.10. - P.71-84. 
6. Farghaly T.A.E.-R., Abdallah M.A., Mahmoud H.K. Synthesis of novel 1,2,4-triazoles and triazolo-thiadiazines as anticancer agents // Turk. J. Chem. - 2015. - Vol.39. - P.955969.

7. Song M.-X., Deng $X .-Q$. Recent developments on triazole nucleus in anticonvulsant compounds: a review // J. Enzyme Inhib. Med. Chem. - 2018. - Vol.33. - No. 1. - P.453-478.

8. Heterocycles 28. synthesis and characterization of some bis and polyhetererocyclic compounds with anti-inflammatory potential / Zaharia V., Silvestru A., Palibroda N., Mogosan C. // Farmacia. - 2011. - Vol.59. - No. 5. - P.624-635.

9. Alrawashdeh M.S.M. Determination of antimicrobial activity of some 1,2,4-triazole derivatives // Reg. Mech. Biosyst. - 2018. - Vol.9. - No. 2. - P.203-208.

10. Advances in 1,2,4-triazepines chemistry / Elattar K.M., Abozeid M.A., Mousa I.A., El-Mekabaty A. // RSC Adv. - 2015. - Vol.5. - P.106710-106753.

11. Synthesis of some new 1,2,4-triazole derivatives starting from 3-(4-chlorophenyl)-5-(4-methoxybenzyl)-4H-1,2,4-triazol with anti-lipase and anti-urease activities / Bekircan O., Mentese E., Ulker S., Kucuk C. // Arch. Pharm. (Weinheim). - 2014. Vol.347. - No. 6. - P.387-397.

12. Antimicrobial activity of 50 plant extracts / Zazharskyi V.V., Davydenko P.O., Kulishenko O.M., Borovik I.V., Brygadyrenko V.V. // Biosystems Diversity. - 2019. - Vol.27. - No. 2. - P.163-169.

13. Chemical composition and antibacterial effect of ethanolic extract of Buxus sempervirens on cryogenic strains of microorganisms in vitro / Palchykov V.A., Zazharskyi V.V., Brygadyrenko V.V., Davydenko P.O., Kulishenko O.M., Borovik I.V. // Chem. Data Collect. - 2020. - Vol.25. - Article No. 100323.

14. Influence of 3-(3-fluorophenyl)-6-(4-methoxyphenyl)$7 \mathrm{H}-[1,2,4]$-triazolo-[3,4-b][1,3,4]thiadiazine on the cultural properties of pathogenic Mycobacterium bovis / Bihdan O., Parchenko V., Zazharskyi V., Fotina T., Davydenko P. // Res. J. Pharm. Biol. Chem. Sci. - 2019. - Vol.9. - No. 6. - P.166-170.

15. Zazharska N., Boyko O., Brygadyrenko V. Influence of diet on the productivity and characteristics of goat milk // Indian J. Anim. Res. - 2018. - Vol.52. - No. 5. - P.711-717.

\section{ФІЗИКО-ХІМІЧНІ ВЛАСТИВОСТІ НОВИХ О-ПОХІДНИХ 5-(5-БРОМФУРАН-2-ІЛ)-4-МЕТИЛ-1,2,4- ТРІАЗОЛ-3-ТІОЛІВ}

\section{В. Зажсарський, М. Парченко, В. Парченко, П. Давиденко, О. Кулішенко, Н. Зажсарська}

Здійснено алкілування 5-(5-бромфуран-2-іл)-4-метил1,2,4-триазол-3-тіолу бромоалканами. Синтез здійснено додаванням бромалкану (бромметан, бромметан, бром бутанбромдекан) до 5-(5-бромфуран-2-іл)4-метил-1,2,4-триазол3-тіолу в метанольному середовищі за наявності еквівалентної кількості натрій гідроксиду. Одержано низку нових сполук із високим виходом. Наступним етапом було дослідження реакції 5-(5-бромфуран-2-іл)-4-метил-1,2,4-триазол-3тіолу з деякими іншими галогеновмісними сполуками, механізм реакції яких також відноситься до реакцій нуклеофільного заміщення. Як галогеновмісні сполуки використовували бромацетон, бромацетофенон, хлорацетатну кислоту та хлорацетамід. В цих умовах було синтезовано низку нових сполук. Структуру сполук підтверджено даними ${ }^{1} \mathrm{H}$ ЯМРспектроскопії. Досліджено антибактеріальну активність синтезованих сполук на кріогенні штами родин Enterobacteriaceae, Pseudomonadaceae, Staphylococcaceae, Bacillaceae, Listeriaceae, Corynebacteriaceae та Saccharomycetaceae in vitro. За отриманими даними можна зробити висновок, що досліджувані сполуки можуть конкурувати 3 канаміцином (природним антибіотиком широкого спектра дії аміноглікозидів другого покоління), спектр дії якого включає грампозитивні та грамнегативні мікроорганізми. Залучені сполуки можуть бути рекомендовані для подальшого дослідження їх впливу на мультирезистентні штами мікроорганізмів.

Ключові слова: S-похідні 1,2,4-триазолу; 3-алкілтіо-4метил-5-(5-бромфуран-2-іл)-1,2,4-триазоли; синтез, фізикохімічні властивості, антибактеріальна активність.

Received 18.03.2020 


\section{PHYSICOCHEMICAL PROPERTIES OF NEW S-DERIVATIVES OF 5-(5-BROMOFURAN-2-YL)-4- METHYL-1,2,4-TRIAZOL-3-THIOLS}

\section{Zazharskyi a, ", M. Parchenko ${ }^{b}$, V. Parchenko ${ }^{b}$, P. Davydenko ${ }^{a}$, O. Kulishenko ${ }^{a}$, N. Zazharska ${ }^{a}$}

a Dnipro State Agrarian and Economic University, Dnipro, Ukraine

' Zaporizhzhia State Medical University, Zaporizhzhia, Ukraine * e-mail: zazharskiyv@gmail.com

The alkylation of 5-(5-bromofuran-2-yl)-4-methyl-1,2,4triazole-3-thiol with bromoalkanes was carried out. Synthesis was accomplished by addition of equivalent amounts of bromoalkanes (bromomethane, bromoethane, bromobutane-bromodecane) to 5-(5-bromofuran-2-yl)-4-methyl-1,2,4-triazole-3-thiol in a methanol medium in the presence of an equivalent amount of sodium hydroxide. Compounds were obtained with a high yield. The next step was to investigate the reaction of 5-(5-bromofuran2-yl)-4-methyl-1,2,4-triazole-3-thiol with some other halogencontaining compounds, the mechanism of the reaction of which also relates to nucleophilic substitution. As halogen-containing compounds, we used bromoacetone, bromoacetophenone, chloroacetic acid and chloroacetamide. Under these conditions, a series of new compounds were synthesized. Structure of compounds was confirmed by ${ }^{1} \mathrm{H}$ NMR spectroscopy and elemental analysis. The antibacterial activity of the synthesized compounds towards cryogenic strains of Enterobacteriaceae, Pseudomonadaceae, Staphylococcaceae, Bacillaceae, Listeriaceae, Corynebacteriaceae and Saccharomycetaceae families in vitro was also investigated. According to the data obtained, one can conclude that the investigated compounds can compete with kanamycin, a natural broad-spectrum antibiotic from the second generation of aminoglycosides, whose range of action includes gram-positive and gram-negative microorganisms. The compounds involved may be recommended for further investigation of their action against multi-resistant strains of microorganisms.

Keywords: S-derivatives of 1,2,4-triazole; 3-alkylthio-4 methyl-5-(5-bromofuran-2-yl)-1,2,4-triazoles; synthesis; physicochemical properties; antibacterial activity.

\section{REFERENCES}

1. Saadaoui I., Krichen F., Ben Salah B., Ben Mansour R., Miled N., Bougatef A., Kossentini M. Design, synthesis and biological evaluation of Schiff bases of 4-amino-1,2,4-triazole derivatives as potent angiotensin converting enzyme inhibitors and antioxidant activities. Journal of Molecular Structure, 2019, vol. 1180, pp. 344-354.

2. Bihdan O.A., Parchenko V.V. Some aspects of synthesis 3-(2-florphenyl)-6-R1-[1,2,4]triazol[3,4-b][1,3,4]thiadiazole and 3-(2-,3-ftorphenyl)-6-R2-7H[1,2,4]triazolo[1,3,4]tiadiazines. Research Journal of Pharmaceutical, Biological and Chemical Sciences, 2018, vol. 9, no. 3, pp. 463-470.

3. Bihdan O., Parchenko V., Zazharskyi V., Fotina T., Davydenko P. Studying of physico-chemical properties of 5-(2-,3-fluorophenyl)-4-((aryl-, geteryl) yliden) amino-1,2,4triazole-3-thiols and any of their retrievalproducts. Research Journal of Pharmaceutical, Biological and Chemical Sciences, 2019, vol. 10 , no. 1, pp. 464-474.
4. Richards D., Coleman J., Reynolds J., Aronson J., Oxford handbook of practical drug therapy, Oxford University Press, Oxford, New York, 2011.

5. El-Sherief H.A.H., Hozien Z.A., El-Mahdy A.F.M., Sarhan A.A.O. One pot synthesis and reactions of novel 5-amino[1,3]thiazolo[3,2-b][1,2,4]triazoles. Arkivoc, 2011, vol. 10, pp. 71-84.

6. Farghaly T.A.E.-R., Abdallah M.A., Mahmoud H.K. Synthesis of novel 1,2,4-triazoles and triazolo-thiadiazines as anticancer agents. Turkish Journal of Chemistry, 2015, vol. 39, pp. 955-969.

7. Song M.-X., Deng X.-Q. Recent developments on triazole nucleus in anticonvulsant compounds: a review. Journal of Enzyme Inhibition and Medicinal Chemistry, 2018, vol. 33, pp. 453-478.

8. Zaharia V., Silvestru A., Palibroda N., Mogosan C. Heterocycles 28. Synthesis and characterization of some bis and polyhetererocyclic compounds with anti-inflammatory potential. Farmacia, 2011, vol. 59, no. 5, pp. 624-635.

9. Alrawashdeh M.S.M. Determination of antimicrobial activity of some 1,2,4-triazole derivatives. Regulatory Mechanisms in Biosystems, 2018, vol. 9, no. 2, pp. 203-208.

10. Elattar K.M., Abozeid M.A., Mousa I.A., El-Mekabaty A. Advances in 1,2,4-triazepines chemistry. RSC Advances, 2015, vol. 5, pp. 106710-106753.

11. Bekircan O., Mentese E., Ulker S., Kucuk C. Synthesis of some new 1,2,4-triazole derivatives starting from 3-(4-chlorophenyl)-5-(4-methoxybenzyl)-4H-1,2,4-triazol with anti-lipase and anti-urease activities. Archiv der Pharmazie - Chemistry in Life Sciences, 2014, vol. 347, no. 6, pp. 387-397.

12. Zazharskyi V.V., Davydenko P.O., Kulishenko O.M., Borovik I.V., Brygadyrenko V.V. Antimicrobial activity of 50 plant extracts. Biosystems Diversity, 2019, vol. 27, no. 2, pp. 163-169.

13. Palchykov V.A., Zazharskyi V.V., Brygadyrenko V.V., Davydenko P.O., Kulishenko O.M., Borovik I.V. Chemical composition and antibacterial effect of ethanolic extract of Buxus sempervirens on cryogenic strains of microorganisms in vitro. Chemical Data Collections, 2020, vol. 25, article no. 100323.

14. Bihdan O., Parchenko V., Zazharskyi V., Fotina T., Davydenko P. Influence of 3-(3-fluorophenyl)-6-(4-methoxyphenyl)-7H-[1,2,4]-triazolo-[3,4-b][1,3,4]thiadiazine on the cultural properties of pathogenic Mycobacterium bovis. Research Journal of Pharmaceutical, Biological and Chemical Sciences, 2019, vol. 9, no. 6, pp. 166-170.

15. Zazharska N., Boyko O., Brygadyrenko V. Influence of diet on the productivity and characteristics of goat milk. Indian Journal of Animal Research, 2018, vol. 52, no. 5, pp. 711-717. 